\title{
New Paradigm: HR Professional Transformation in Manufacturing Company
}

\author{
Abd. Rasyid SYAMSURI ${ }^{\star}$, Ritha F. DALIMUNTHE ${ }^{2}$, Parapat GULTOM ${ }^{3}$, Elisabet SIAHAAN ${ }^{4}$ \\ ${ }^{1}$ Doctoral Program of Management Science, Universitas Sumatera Utara, Medan, Indonesia, Email: \\ abd.rasyidsyamsuri@students.usu.ac.id \\ 2,3,4 Faculty of Economy and Business Universitas Sumatera Utara, Medan, Indonesia \\ ${ }^{*}$ Corresponding Author
}

\author{
Received: 09.11.2021 \\ Accepted: 14.12.2021 \\ Published: 01.02.2022 \\ DOI: $10.47750 / Q A S / 23.186 .16$
}

\begin{abstract}
This study aimed to optimize the line managers performances in the human resources (HR) division in answering the role of the HR management function problem in Medan City Manufacturing Company. The novelty proposed is a concept of HR management called "Human Resources Professional Transformation". Specifically, this concept discussed the ability of HR division line managers to make adaptive changes to the company's business-oriented functional divisions with managerial competence, commitment, innovation capability, and readiness for changes towards work performance. The population of this research was the line manager of the HR division, totaling 185 respondents. The sampling technique used a probability sampling approach with simple random sampling through the slovin formula, totaling 126 respondents. The analytical tool used is structural equation software through the SmartPLS application program. The results showed that managerial competence, commitment, innovation capability had a positive and significant effect through the HR professional transformation on the performance of line managers in the HR division. Meanwhile, readiness for change has a positive and insignificant effect on the HR Professional Transformation. Readiness for change also has a positive and insignificant effect on the Line Managers Performances in the Human Resources Division through HR Professional Transformation. Based on the suitability test of the research model, it proved that the HR Professional Transformation can answer the problem of the role of the management function to improve the line managers performances in the HR division with managerial competence, commitment, innovation capability, and readiness for change of 0.907.
\end{abstract}

Keywords: Managerial Competence; Commitment; Innovation Capability; Readiness for Change; HR Professional Transformation; HR Division Line Manager Performance.

\section{Introduction}

The industrial revolution era 4.0 is the digitalization of technological processes to create new value into corporate practice. This implementation can be done by systematizing the manifestation of digitalization, calculating risks and hazards, developing appropriate corporate policy measures and creating innovative transformations in the company (Morkovkin, et al., 2020). HR Division line managers can transform HR functions which can improve efficiency and cognitive technology by automating HR functions. Companies that implement the automation of HR functions will simplify and make the work of HR managers more effective. The active involvement of functional managers in the HR division can integrate personnel management processes into business processes, both in making decisions based on the HR system and conducting job analysis dynamically, (Sotnikova., et al, 2020). Torraco (2020), added that HR transformation has a direct contribution to the growth and development of business strategies. The implications of HR transformation are related to operations and business dynamics as well as company performance. Successful HR transformation will be beneficial for the implementation of decisions in terms of skill development, creativity, collaboration, technology use, artificial intelligence, and job automation as a form of professional HR development. This perspective became the basis that changes in HR are needed for the company as a form of transformation for the future. According to Purba, et al (2020), skills can also be interpreted as an ability and capacity obtained through systematic and ongoing efforts in a smooth and adaptive manner in carrying out complex activities or job functions that involve ideas or cognitive skills, matters or technical skills, and interpersonal skills. Fu, et al., (2020) suggested that the responsiveness of line managers when doing work on the implementation of HR management will provide more flexible working conditions. The line manager's performance will become an effort and ability to do the work that can be seen from the implementation of the resulting resources. Line managers who have high work performance will have a positive impact on the company. Bag and Pretorius (2020) added, 14.0 technology can be a valuable asset for managers (including line managers in the HR division) in making quality decisions to achieve superior performance. The company will fail to achieve the desired level of performance if it does not acquire the resources to implement the 14.0 technology.

According to Vallina, et al (2021), HR management orientation from the performance of line managers in the HR 
division will excel if it is realized through competence, commitment, and maximizing one's self capabilities or abilities. This is also reinforced by Kehoe and Hun (2020) that line managers of the HR division can adapt, introduce HR practices to the companies in making transformative changes with competence, high commitment, make adjustments with capabilities to achieve the implementation of performance management activities. Fareed, et al., (2020) stated that the need to transform the HR management function aims to maintain and follow changes that occur in the company. This encourages HR professionals/managers to address all aspects and fundamentals of work by developing their competencies. Companies that improve their performance should emphasize the professional development of HR with knowledge and expertise. This perspective is certainly focused on human capital as a strategy of human resources to maintain competition within the company. Mtetwa and Mutambara (2020), explained that the transformation of the HR function can overcome management challenges by changing the HR function to be operationally involved, understanding business needs, redefining and aligning strategies and optimal human capital management systems. Changing the HR function has positive implications for management in the company by ensuring that transformation efforts are directed to specific issues for measuring and evaluating progress effectively. In addition, process implementation must be based on a good understanding of the business context to ensure that the transformation effort supports and enables the business to face the changes and challenges presented by the work environment. Subramony, et al., (2020) stated that the function of most HR professionals is focused on specific knowledge and skills of HR management that have human capital and credibility to implement HR management policies and practices. HR professionals reflect the increased ability of the HR function to design and implement policies and practices. Furthermore, the role of HR professionals in working with stakeholders enforces and facilitates implementation through line managers of existing practices or policies within the company. According to Panda (2020), business strategy acumen, coaching and skills with empathy, and a talent for technology are new additions to the $\mathrm{HR}$ professional skill set. On the other hand, the role of HR will be transformed into a strategic business partner.

Mercer Consulting Group in the Indonesian Edition of Global Talent Trends study (2021), stated that currently, the impact of Covid-19 also affects the ability of a manufacturing company to operate in Indonesia. HR managers/leaders in Indonesia from various manufacturing companies who participated in the survey stated that $73 \%$ of the Covid-19 impact had negatively impact business. Only $37 \%$ of companies in Indonesia that implement HR capability-based strategies. The survey results from the transformation plans of Indonesian companies for organizational sustainability, workforce adaptability (acquisition of new skills and involvement) and redesign of $\mathrm{HR}$ strategies can be seen in Figure 1:

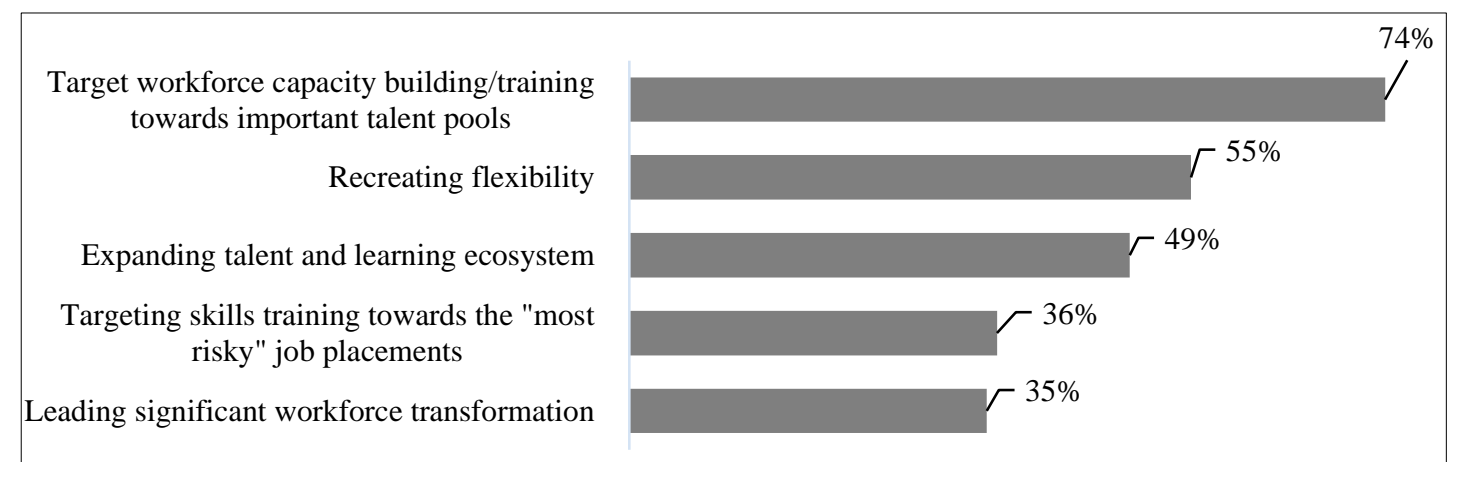

Figure 1:: Indonesian Company Transformation Plan Source: Mercer Consulting Group Global Talent Trends Study, (2021)

Figure 1. The transformation plan of Indonesian companies, in this Global Talent Trends study, shows that only $35 \%$ of Manufacturing Companies that undergo a significant transformation of their workforce. According to the Mercer Consulting Group Global Talent Trends Study (2021) the main challenge to the success of corporate transformation is due to not having the right skills to be able to implement workforce transformation both in the managerial environment and in the company environment. Surely, the decision to develop skills within the company is focused on the abilities of the Managers including the HR division to stay ahead in achieving success. Portrait of the National and regional Manufacturing industry during the Covid-19 pandemic in Indonesia published by PT. Sarana Multi Infrastruktur (Persero) Indonesia (2021) also stated that the performance of the manufacturing industry (managers and employees) in North Sumatra in the second quarter of 2019 and 2020 has experienced negative growth. The percentage of manufacturing companies performance in North Sumatra is $(-1.32 \%)$, this is due to the global economy weakening because of the covid-19 outbreak. This decline in performance was motivated by the Large-Scale Social Restriction policy adopted by the Government to limit mobility and economic activity in order to contain the wider spread of Covid-19. This implication is focused on the limited supply of raw materials, most of which must be imported. The reduced performance of the manufacturing industry is also due to restrictions on the company's operating hours. The condition of improving the manufacturing companies performance in Indonesia is expected to improve starting in 2021 with the assumption that the handling of Covid-19 such as the vaccine administration program runs optimally.

Based on the phenomenon studied at a macro level, it can be illustrated that the problems experienced by manufacturing companies in the Medan city have an indication of the problems experienced by manufacturing companies in Indonesia and a review of conditions in North Sumatra. Beside the impact of the Covid-19 pandemic, the imbalance in the availability of manpower at the managerial level and the lack of expertise in implementing work has led to a decline in the quality of human resources. The high level of rigidity and the 
incompetent ability to be able to work in the company's management, especially the HR Division Line Manager, must be a concern for manufacturing companies in the Medan city. Based on the explanations and research phenomena described, the researchers offer a new concept to overcome the problems that occur in manufacturing companies, especially Medan City Manufacturing companies as a solution for achieving company goals and success. The novelty of this research is collaborating the conceptualization of the theoretical application of HR Analysis, HR Professionals and HR Transformation. This theory application formed a seamless synthesis novelty of Human Resources Professional Transformation. The foundation for pushing transformation in the scope of work of line managers in the HR division focuses on managerial competence, commitment, innovation capability, readiness for change and performance.

\section{Literature Review}

\subsection{Managerial Competence}

Niazi, et al., (2020) suggested that managerial competence is the skills, knowledge, abilities and personal traits of managers needed for effective performance. Managerial competence can be analyzed from two aspects, they are: managerial skills and general characteristics. According to Pauliene (2017), managerial competence is a behavioral skill including self-awareness, openness, self-confidence and creativity. Managerial competencies are based on: Cognitive intelligence competencies consist of developing others (developing employees), holding people accountable (having responsibility) and team leadership, Social intelligence competence consists of result orientation; imitativeness; problem solving; influencing others; building teamwork, Emotional intelligence competencies consist of empathy, selfcontrol, and self-confidence. The long-term success of a new leadership development initiative depends on managerial competence, two-way interaction between the leader and other organizational members, reciprocity and feedback. Lupicka and Gryzbockawska (2018) stated that managerial competence is a skill that includes analytical skills and research skills, conflict resolution, problem solving, creativity and the ability in making decisions. Some indicators of managerial competence consist of: Creativity refers to the ability in understanding the environment in new ways, discover hidden patterns, make connections between unrelated phenomena, and generate solutions. Thinking about entrepreneurship is skills that refer to the ability to identify market opportunities and find the most appropriate way and time to take advantage of them. Problem solving, which involves comparing, evaluating, and choosing skills as well as being creative in using imagination in creating a number of ideas for solutions. Conflict solving is a key part of the manager's role that requires emotional maturity, self-control, and empathy. Decision making is the process of making choices by identifying, gathering information, and assessing alternative resolutions. Analytical skills are the ability to visualize, gather information, articulate, analyze, solve complex problems, and make decisions. Research skills are acquired from the need to be able to use reliable sources in a learning process of a changing environment. Efficiency orientation is an approach that emphasizes the efficient use of resources as the main determinant of decisions and actions.

Managerial competence is the managers ability and skills in managing, planning and organizing activities for problem solving and decision making. Managers can take responsibility for implementing wishes and negotiating with the necessary authorities, setting specific and realistic goals to determine priorities and qualities related to the work performed. Managers must engage in proper self-management to realize team supervision, maintain a balance between task orientation and individual orientation, individual needs and organizational needs, willing for change, innovation, preserve continuity and predictability, (Bayer, et al., 2020). Shun and Wang, (2020), illustrated that managerial competence is the capacity for knowledge, skills, abilities and personalities needed to develop a framework at the management level. Managerial competence can be focused on handling management tasks in doing work. Managers who have managerial competence can improve performance, develop organizational talent, change leadership when necessary, and improve decision-making abilities. The manager decision-making ability quickly and surely shows the quality of a manager who helps determine the main tasks of the company and fulfills the required level of responsibility.

\subsection{Commitment}

According to Colquitt, et al., (2019), organizational commitment is an employee's desire to remain a member of the organization (retained) or pursue another job (turn around). Organizational commitment consists of: First, affective commitment is the desire to remain the organization member because of emotional attachment, and involvement with the organization. Individuals who are more emotional and intuitive by nature, basicly are focused on feelings. Affectively committed managers reflect an emotional attachment to the organization and tend to go the extra mile for the organization's goals and values. Second, continuance commitment which is the desire to remain the organization member because of the the costs associated awareness with leaving the organization. Some of the factors that increase continuance commitment are the total amount of investment (in terms of time, and effort) that employees make to fulfill organizational tasks. Another factor that increases continuance commitment is the lack of alternative employment. If an employee has nowhere else to go to leave the organization, the need to stay will be higher. Continuing commitment tends to create a more passive form of loyalty. Third, normative commitment as a desire to remain a member of an organization because of obligations. Normative commitment relates to norms or morals that must be done, trust, justice and ethics.

Moussa and Arbi (2020) suggest that commitment is defined as a psychological state that reflects the nature of the relationship between employees and the organization. The three types of commitment are affective commitment, continuance commitment, and normative commitment. Normative commitment is the obligation to remain and continue a work in the organization. Continuing commitment is the desire to remain in the organization because of the psychological state of the associated costs. Continuous commitment is focused on the deficit conditions experienced by employees when they leave the organization. Pascual, et al., (2020) stated that commitment is the core of the type of $\mathrm{HR}$ relationship that is applied in the company's business environment. Commitment consists of: effective commitment (identification with emotional involvement and attachment to the company), continuance commitment (retention or obligation for a company to retain employees due to high exit costs) and normative commitment (decision to remain in the company because of moral obligation). Affective commitment is the best commitment because it has important benefits for the company. Affective commitment is related to behaviors within the company such as sharing new knowledge, helping 
each other, doing extra work, and ethical behavior. Kokubun and Yasui (2020) added that high commitment is related to various job outcomes such as performance and ethical behavior. Commitment is the relative strength of individual identification with involvement in the organization. In the company, managers and employees must have sensitivity in developing the right commitment in the workplace. Managers and employees must know the clear role in doing their work duties and responsibilities for better performance.

\subsection{Innovation Capability}

Saunila (2019) stated that innovation capability is the ability to continuously change knowledge and ideas, processes and systems for the benefit of the company and stakeholders. Innovation as a process consists of being ready to examine new ideas and ways of doing things, as well as having creativity in operational ways. Innovation as a result is the ability and capacity to produce different types of innovation. Individual innovation capabilities become interrelated capabilities and have an impact on performance. Managers can increase the company's capabilities to innovate with innovation capabilities. Le and Lei, (2019) argued that innovation capability is the organization's ability to provide processes from operations to get a better performance. Helping Directors/ Managers to understand the factors, processes, and mechanisms that influence innovation, exploration of the form of corporate ownership must be influenced by the transformation from knowledge sharing to become a better innovation. Research conducted by Nham, et al., (2020) stated that individual innovation capability is the willingness to adopt something new and the ability to create new ideas in achieving personal and organizational goals. Individual innovation capability becomes an individual's ability and tendency to create and implement new ideas to achieve organizational goals. It can also be seen as an individual's new perspective on emerging problems, willingness to take risks and tolerance for ambiguity.

Innovation capability is the ability to manage and create a long term innovation. Innovation is the result of a process that relies on interactions that promote the identification and assimilation of new knowledge. This category of individual activity considers the tasks and roles in innovation management. Considering other characteristics such as values, skills, and attitudes towards the company's innovation process is also an individual characteristic to turn it into innovation. Thus, organizational capacity to innovate has become an important booster of organizational success (Mendoza and Silva 2020). Capability is the capacity or ability of all employees in the company to access the information needed in their work, understand and interpret the information needed as a solution to company problems. The ability to innovate or make a difference in the management approach, input, process, output and corporate image can be done by implementing effective additional value in the company's choices. The additional value of capability as an innovation in the company can be focused on managerial capability which is a collection of knowledge, mastery, characteristics, motives, values, attitudes and behaviors that ensure the achievement of an effective and successful manager's task. Systems development capabilities or systems development and operational strategies are based on the managers' abilities functions such as learning, time management, communication, information processing, innovation, team management, comprehensive thinking, harmonization, and conceptual skills. The company's capability strategy can also create a competitive advantage in terms of agility capability which is a fast and competent response to expectations and changes
(Karakoc, 2020)

\subsection{Readiness for Change}

According to Kirrane, et al., (2017), readiness for change is an individual's belief, awareness and intention as well as an organization's capacity to implement successful and beneficial changes. The category for change readiness consists of climate-based factors, which relate to the internal state of the change that occurs including the organization's level of trust in leadership. Process-based factors, relate to the way change is managed and consist of the quality of communication, participation, management's attitude towards change, and supervisor support for change. Ridell and Roisland (2017) suggested that readiness for change is a tool to reduce resistance (attitude to persist) towards change. A company manager, both line manager of the HR division, can make efforts to create readiness for change by reducing the resistance and turning employees into change agents. Making change efforts will also help employees to adopt with the behaviors that are essential to the company's success. The readiness of change measurement consists of: Discrepancy (belief that change is needed by the organization); Principal support (management support); Self-efficacy; Appropriate (accuracy to make changes) and Personal valence (benefits for individuals).

Research conducted by Matthysen and Harris (2018) readiness for change is an important element for the success of implementing organizational change. The ten measures of readiness for change are: quality of communication change, participation, top management attitude, support by supervisors, trust in leadership, cohesion, political, emotional readiness for change, cognitive readiness to change and intentional readiness to change. According to Kosasih et al., (2020), readiness for change is the ability of the organization and its members to deal with the planned change process, so that the goals of change can be achieved effectively and efficiently.

\subsection{HR Professional Transformation}

The novelty in this research was the Human Resources Professional Transformation obtained from the synthesis of research (attached) sourced from: Human Capital Theory, a theory proposed by Becker (1964), HR Work: Ulrich and Dulebhoni (2015), Theory of HR Strategy: Schuler and Walker (1990), Business Context: Losey., et al (2005), Organizational Capability: Yeung, et.al., (1999), Organizational Learning Theory: Argyris and Schon (1978), HR Professionals: Schuler and Jackson (2005), Jackson, et al., (2014); Cooke et al., (2020), HR Transformation: Ulrich, et al., (2009); Sousa and Dias (2020), HR Analysis: Heuvel and Bondarouk (2017); Zeidan and Itani (2020). Human Resources Professional Transformation is the ability of HR division line managers to make adaptive changes to the company's business-oriented functional divisions. In the process of implementing the HR professional transformation, the company collaborates with the individual capabilities/talents of HR division line managers to improve innovation, knowledge management capacity, implement change with a shared belief in making changes effective. Developing talent as a novelty of these skills can be applied in the form of managerial competence, commitment, innovation capability and having readiness for change to improve performance. Human Resources Professional Transformation has variable dimensions consisting of: Business intelligence, Using artificial intelligence and Redesigning the HR division function. Measurement of variable dimensions using dimensions developed from Zeidan and Itani, (2020), Sousa and Dias 


\section{GENERAL MANAGEMENT}

(2020), Cooke et al., (2020), Heuvel and Bondarouk (2017), Ulrich, et al (2009), Ulrich and Dulebhon (2015), which are combined into a unity. Each of these variable dimensions consists of several indicators which include: Response to business challenges, Monitoring business development, Increasing business speed, Information Technology Skills, Automating manual work, Performing routine HR activities, Collaborating systems between HR divisions, Implementing partnership skills, Increasing accountability in the business. (Measurement of indicators by using indicators developed by Heuvel and Bondarouk (2017), Zeidan and Itani (2020), Jackson, et al (2014), Sousa and Dias (2020), Ulrich, et al (2009), Ulrich and Dulebhon (2015), which are combined into a unity). The synthesis of HR Professional Transformation can be seen in Figure 2:

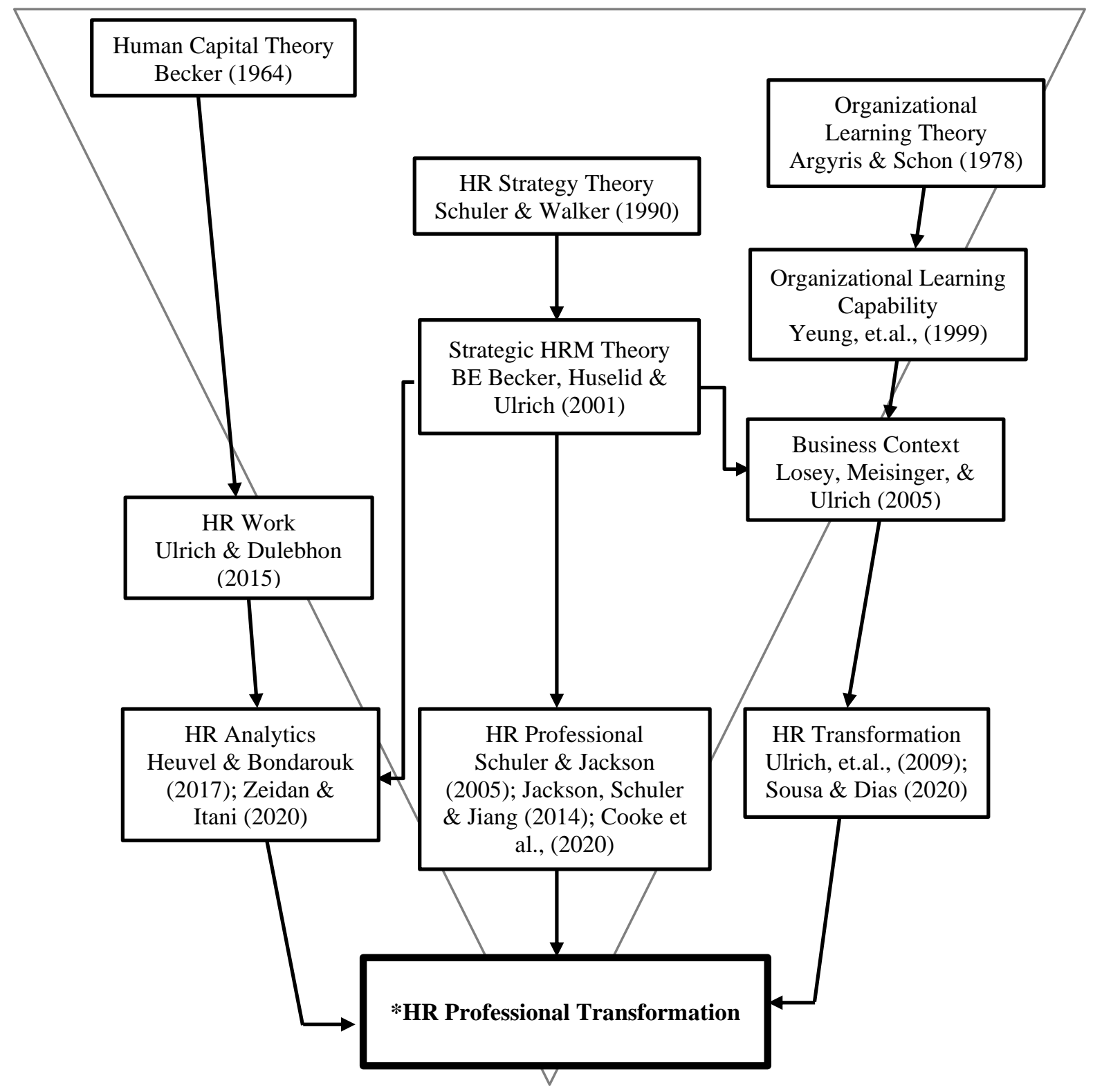

Figure 2: The Synthesis Concept of Human Resources Professional Transformation

\subsection{HR Division Line Manager Performance}

According to Mitchell and Gamlem (2017), performance is the skills use, knowledge, and tools to complete a task or job. In the company, Managers must be able to accept responsibility for success or failure in doing work, evaluate work accurately, be able to adapt to changes and help employees to adapt, care about employees, and communicate performance expectations clearly. Performing tasks, being reliable, and having accuracy so they will be able to support the company's goals. A study conducted by Liu (2017) states that line managers have a role as a bridge between employees and higher-level managers, who are in charge of conveying information and managing employees. The line manager's work in the HR division includes quality improvement, continuous improvement and optimization of manpower allocation. To realize effective HR management, the HR division must cooperate with other division managers in completing management activities in supervising the transmission and implementation responsibilities. HR management practices in the company will vary, and HR management activities will no longer be limited to the responsibility of the HR Division. Latham (2018) suggested that the ability to fulfill a manager's potential at work is 


\section{GENERAL MANAGEMENT}

obtained through positive feedback in the job. Managers are able to obtain job-related information to assist reliability as a quality assessment by analyzing work focused on vision and goals. The business plan determined to achieve the goals conducted by the manager will effectively bring the desired results in the organization.

The study conducted by Lee et al., (2020), the most important part of the line manager's role is ensuring that employee performance meets organizational goals. Line managers link the performance management system through components and processes developed by the HR Division and higher management levels with employee performance. Formal and informal systems interact in performance management, because line managers are a key role in informal performance management systems. The results showed that the most important part of the line manager's role is to ensure that employee performance meets organizational goals through formal and informal performance management systems. According to Panagiotakopoulos (2020), improving the skills of all types of workers, including managers, is at the core of company performance. Companies can place HR strategies and management development in the long term, related to the company's specific competency needs. Companies can explore management training for the achievement of company performance. The importance of this learning will help managers to manage change. The results of this study indicate that there was a positive relationship between management training for managers on organizational performance which helps to manage effective change in the company.

\section{Method Research}

The research location in the novelty theoretical development of Human Resources Professional Transformation was conducted in Manufacturing Companies spread across Medan city with the subject in this research was the Line Manager of the Human Resources Division. The population in this study is the HR Division Line Manager at a manufacturing company in Medan city in 2021. The population was adjusted to the data information obtained from the Industrial Chamber of Commerce in 2021 which was spread over 21 sub-districts in Medan City, including: Amplas Medan district, Medan Area, West Medan, Medan Baru, Medan Belawan, Medan Deli, Medan Denai, Medan Helvetia, Medan Johor, Medan Kota, Medan Labuhan, Medan Maimun, Medan Marelan, Medan Struggle, Medan Petisah, Medan Polonia, Medan Sunggal, Medan Selayang, Medan Tembung, Medan Tuntungan, and Medan Timur with the total population of 185 people. The technique for determining the sample in this study was a simple random sampling technique that is a technique of randomly sampling the population. Determination of the sample using the Slovin formula with an error rate (e) of $5 \%$, then the sample size is $126 \mathrm{HR}$ Division Line Managers at Manufacturing Companies in Medan City, in 2021. The data collection methods used were Observation, Interview and Questionnaire with sources primary and secondary research data. This research analysis method used SmartPLS in determining the effect between the observed research variables. According to Sekaran and Bougie (2016), conceptual models explain ideas related to variables in a model. The schematic diagram of the conceptual model can visualize the theorized relationships among the variables in the model. The conceptual framework of the Managerial variables Competence, Commitment, Innovation Capability, Readiness for Change, Human Resources Professional Transformation and Line Managers Performances in the Human Resources Division can be contained in Figure 3:

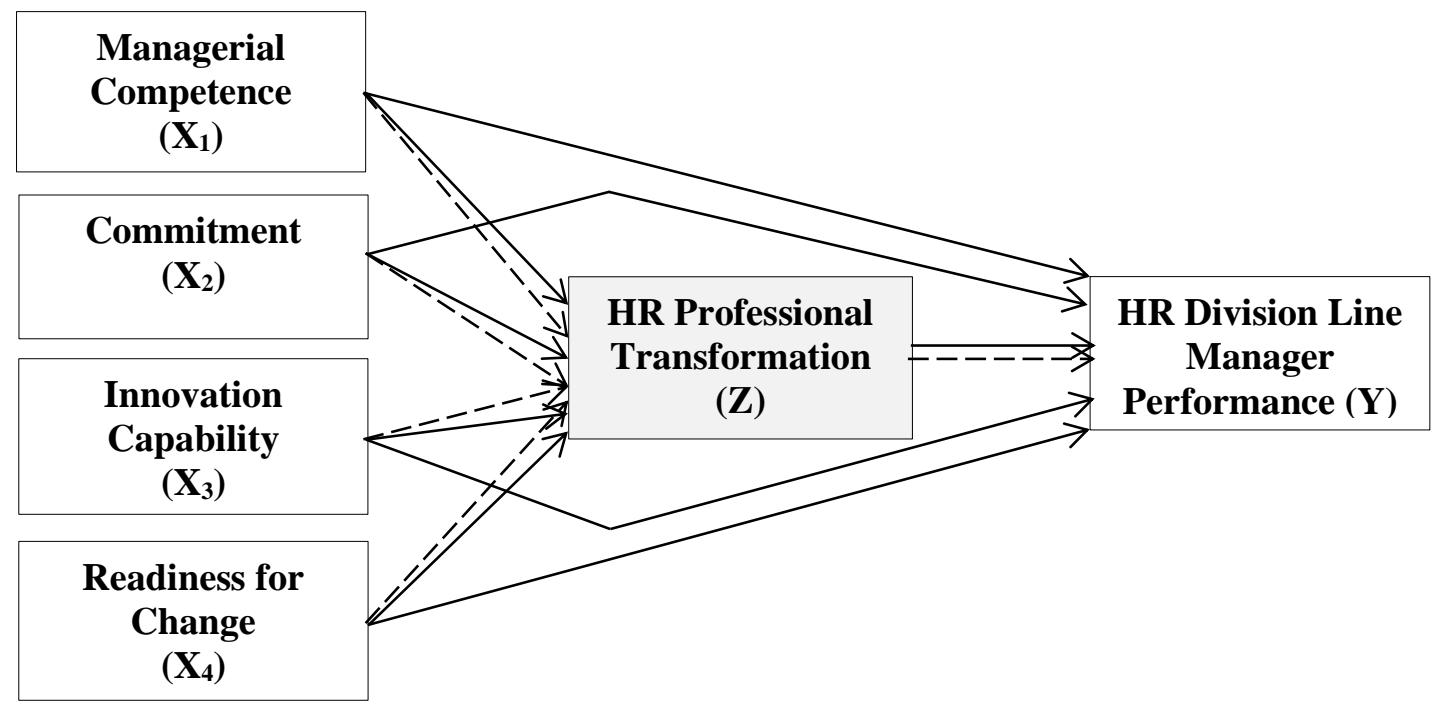

Figure 3: Conceptual Framework

Source: Research Development Results, (2021)

\section{Results And Discussion}

Inferential analysis in this study used the structural equation method with the SmartPLS program. In testing the structural model, evaluation was conducted through the results of $t$-statistics of the direct influence between variables, indirect and total influence with significance through the path parameter coefficients. The evaluation of the structural model was also explained based on the R-square value to determine the percentage variance of the endogenous latent construct, the Q-square test to test the model fit (goodness of fit). The test of this structural model is obtained from the bootstrapping process (a statistical method for estimating the sampling distribution of the estimator based on the research sample). The results of the structural model through the bootstrapping process in the SmartPLS program were analyzed by looking at the relationship between the constructs. The statistical $t$ value 


\section{GENERAL MANAGEMENT}

in the structural model can be obtained from the estimated path coefficient value with the decision criteria 1.96. The fulfilled decision criteria will indicate that the research measurement model has produced a variable model and met the structural measurement criteria. The testing results about the research variables direct influence can be seen in Table1:

\begin{tabular}{|c|c|c|c|c|c|}
\hline & $\begin{array}{l}\text { Original } \\
\text { Sample } \\
\text { (O) }\end{array}$ & $\begin{array}{l}\text { Sample } \\
\text { Mean } \\
(\mathrm{M})\end{array}$ & $\begin{array}{l}\text { Standard } \\
\text { Deviation } \\
\text { (STDEV) }\end{array}$ & $\begin{array}{l}\text { Tr Statistics } \\
(|\mathrm{O} / \mathrm{STDEV}|)\end{array}$ & $\begin{array}{l}\text { P } \\
\text { Values }\end{array}$ \\
\hline $\begin{array}{l}\text { Innovation Capability }(\mathrm{X} 3) \rightarrow \mathrm{HR} \text { Division } \\
\text { Line Manager Performance }(\mathrm{Y})\end{array}$ & 0.341 & 0.341 & 0.034 & 9.881 & $0.000^{*}$ \\
\hline 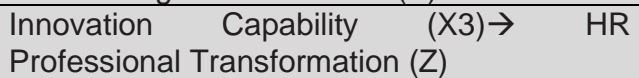 & 0.312 & 0.315 & 0.075 & 4.156 & $0.000^{*}$ \\
\hline $\begin{array}{l}\text { Readiness for Change }(\mathrm{X} 4) \rightarrow \mathrm{HR} \text { Division } \\
\text { Line Manager Performance }(\mathrm{Y})\end{array}$ & 0.378 & 0.373 & 0.057 & 6.599 & $0.000^{*}$ \\
\hline $\begin{array}{lll}\text { Readiness for Change }(X 4) \rightarrow & \text { HR } \\
\text { Professional Transformation }(Z) & & \\
\end{array}$ & 0.184 & 0.172 & 0.099 & 1.862 & $0.063^{*}$ \\
\hline $\begin{array}{l}\text { Commitment }(\mathrm{X} 2) \rightarrow \mathrm{HR} \text { Division Line } \\
\text { Manager Performance }(\mathrm{Y})\end{array}$ & 0.276 & 0.274 & 0.031 & 8.806 & $0.000^{*}$ \\
\hline $\begin{array}{lccc}\text { Commitment } & (\mathrm{X} 2) \rightarrow & \text { HR } & \text { Professional } \\
\text { Transformation }(\mathrm{Z}) & & \\
\end{array}$ & 0.230 & 0.229 & 0.068 & 3.378 & $0.001^{*}$ \\
\hline $\begin{array}{l}\text { Managerial Competence }(\mathrm{X} 1) \rightarrow \mathrm{HR} \text { Division } \\
\text { Line Manager }\end{array}$ & 0.247 & 0.244 & 0.026 & 9.600 & $0.000^{*}$ \\
\hline \multicolumn{6}{|l|}{ Performance (Y) } \\
\hline $\begin{array}{lll}\text { Managerial Competence }(\mathrm{X} 1) \rightarrow & \mathrm{HR} \\
\text { Professional Transformation }(\mathrm{Z}) & & \end{array}$ & 0.151 & 0.147 & 0.060 & 2.517 & $0.012^{*}$ \\
\hline $\begin{array}{l}\text { HR Professional Transformation }(\mathrm{Z}) \rightarrow \mathrm{HR} \\
\text { Division Line Manager Performance }(\mathrm{Y})\end{array}$ & 0.189 & 0.188 & 0.027 & 6.899 & $0.000^{*}$ \\
\hline
\end{tabular}

Table 1: Path Coefficients Mean, STDEV, T-Value, P-Values

Notes: ${ }^{*} p<0.05$.

Source: Research Results, 2021

Based on Table 1, it can be determined that the structural equations of direct influence between variables are as follows:Managerial Competence (X1) directly has a positive and significant influence on HR Professional Transformation (Z) with the structural equation $Z=0.151 \mathrm{X} 1$, the t-statistical value of $2.517 \geq$ t-table 1.96 and the significant level $\leq 0.05$ is 0.012. Managerial Competence (X1) directly has a positive and significant effect on the HR Division Line Managers Performance $(Y)$ with the structural equation $Y=0.189 \mathrm{X} 1$, the $\mathrm{t}$-statistical value is $6.889 \geq \mathrm{t}$-table 1.96 and significant level $\leq$ 0.05 of 0.000 . The results of the path coefficient test also prove that Commitment (X2) directly has a positive and significant effect on HR Professional Transformation (Z) with the structural equation $Z=0.230 \mathrm{X} 2$, the t-statistical value was $3.378 \geq$ t-table 1.96 and significant level $\leq 0.05$ was 0.001 . Commitment (X2) directly has a positive and significant effect on the HR Division Line Managers Performance ( $Y$ ) with the structural equation $Y=0.276 \mathrm{X}$, the statistical t value is 8.806 $\geq \mathrm{t}$-table 1.96 and the significant level $\leq 0.05$ was 0.000 . The next research direct influence test variable shows that Innovation Capability (X3) has a direct positive and significant effect on HR Professional Transformation (Z) with the structural equation $Z=0.312 \times 3$, the statistical $t$ value was $4.156 \geq \mathrm{t}$-table 1.96 and the significant level $\leq 0.05$ was 0.000. Innovation Capability (X3) directly has a positive and significant influence on the HR Division Line Managers Performance $(Y)$ with the structural equation $Y=0.341 X 3$, the statistical $t$ value was $9.881 \geq t$-table 1.96 and the significant level was $\leq 0.000$.

The results of the structural model test obtained from the bootstrapping process through the coefficient value prove that Readiness for Change (X4) directly has a positive and insignificant effect on HR Professional Transformation $(Z)$ with the structural equation $Z=0.184 X 4$, the statistical t value was $1.862 \leq \mathrm{t}$-table 1.96 and the significant level $\geq 0.05$ was 0.062 . Readiness for Change (X4) directly has a positive and significant effect on the HR Division Line Manager Performance $(Y)$ with the structural equation $Y=0.378 X 4$, the statistical $t$ value was $6.599 \geq t$-table 1.96 and significant level $\leq 0.05$ was 0.000 . The next path coefficient test shows that HR Professional Transformation ( $Z$ ) directly has a positive and significant effect on the HR Division Line Manager Performance $(Y)$ with the structural equation $Z=0.188 \mathrm{Y}$, the statistical $t$ value was $6.899 \geq \mathrm{t}$-table 1.96 and the significant level was 0.000 . The indirect effect in the research model is evaluated based on the relationship between exogenous variables, mediating variables (intervening) on endogenous variables and the research variables dimensions. The testing results about the research variables direct influence can be seen in Table 2 : 


\section{GENERAL MANAGEMENT}

\begin{tabular}{|c|c|c|c|c|c|}
\hline & $\begin{array}{l}\text { Original } \\
\text { Sample } \\
\text { (0) }\end{array}$ & $\begin{array}{l}\text { Sample } \\
\text { Mean } \\
\text { (M) }\end{array}$ & $\begin{array}{l}\text { Standard } \\
\text { Deviation } \\
\text { (STDEV) }\end{array}$ & $\begin{array}{l}\text { Tratistics } \\
(\mid \text { O/STDEV } \mid)\end{array}$ & $\begin{array}{l}\mathbf{P} \\
\text { Values }\end{array}$ \\
\hline $\begin{array}{l}\text { Innovation Capability }(\mathrm{X} 3) \rightarrow \mathrm{HR} \\
\text { Professional Transformation }(\mathrm{Z}) \rightarrow \\
\text { HR Division Line Manager } \\
\text { Performance }(Y)\end{array}$ & 0.059 & 0.059 & 0.017 & 3.563 & $0.000^{*}$ \\
\hline $\begin{array}{l}\text { Managerial Competence }(\mathrm{X} 1) \rightarrow \\
\text { HR Professional Transformation } \\
(\mathrm{Z}) \rightarrow \text { HR Division Line Manager } \\
\text { Performance }(\mathrm{Y})\end{array}$ & 0.029 & 0.028 & 0.013 & 2.224 & $0.026^{*}$ \\
\hline $\begin{array}{l}\text { Readiness for Change }(\mathrm{X} 4) \rightarrow \mathrm{HR} \\
\text { Professional Transformation }(\mathrm{Z}) \rightarrow \\
\mathrm{HR} \text { Division Line Manager } \\
\text { Performance }(Y)\end{array}$ & 0.035 & 0.032 & 0.019 & 1.792 & $0.073^{*}$ \\
\hline $\begin{array}{lll}\text { Commitment } & (\mathrm{X} 2) \rightarrow & \mathrm{HR} \\
\text { Professional Transformation } & (\mathrm{Z}) \rightarrow \\
\text { HR Division } & \text { Line } & \text { Manager } \\
\text { Performance }(Y) & & \\
\end{array}$ & 0.043 & 0.043 & 0.015 & 2.869 & $0.004^{*}$ \\
\hline
\end{tabular}

Table 2: Specific Indirect Effects Mean, STDEV, T-Value, P-Values

Notes: ${ }^{*} p<0.05$.

Source: Research Results, 2021

The results of the indirect effect test of the variables from the path coefficients show that Managerial Competence (X1) has a positive and significant influence on the HR Division Line Managers Performance $(Y)$ through HR Professional Transformation $(Z)$ with the structural equation $Z \rightarrow Y=0.029$ $\mathrm{X} 1$, statistical $\mathrm{t}$ value of $2.224 \geq \mathrm{t}$-table 1.96 and a significant level $\leq 0.05$ of 0.026 . Testing the indirect effect of the following research variables proves that Commitment (X2) has a positive and significant influence on the HR Division Line Managers Performance (Y) through HR Professional Transformation $(Z)$ with the structural equation $Z \rightarrow Y=0.043$ $\mathrm{X} 2$, the statistical $\mathrm{t}$ value was $2.869 \geq \mathrm{t}$-table 1.96 and the significance level $0.05 \leq$ was 0.004 . The structural model test results regarding the indirect effect test of variables based on the path coefficient value show that Innovation Capability (X3) has a positive and significant positive effect on the HR Division Line Managers Performance $(Y)$ through HR Professional Transformation $(Z)$ with the structural equation $Z \rightarrow Y=0.059$ $X 3$, the statistical $t$ value was $3.563 \geq$ t-table 1.96 and the significant level $\leq 0.05$ was 0.000 . The coefficient value obtained from the bootstrapping process in the SmartPLS program also proves that Readiness for Change (X4) has a positive and insignificant effect on the HR Division Line Managers Performance $(Y)$ through HR Professional Transformation $(Z)$ with the structural equation $Z \rightarrow Y=0.035$ $X 4$, the statistical $t$ value was $1.792 \leq$ t-table 1.96 and the significant level $\geq 0.05$ was 0.073 . Th total effect results of the relationship between exogenous variables on endogenous variables and the intervening variables effects can be summarized in Table 3:

\begin{tabular}{|l|l|l|l|l|}
\hline & \multicolumn{2}{|l|}{ Original Sample (O) } \\
\cline { 2 - 4 } & $\begin{array}{l}\text { Direct } \\
\text { Effect }\end{array}$ & $\begin{array}{l}\text { Indirect } \\
\text { Effect }\end{array}$ & $\begin{array}{l}\text { Total } \\
\text { Effect }\end{array}$ & $\begin{array}{l}\text { P } \\
\text { Values }\end{array}$ \\
\hline $\begin{array}{l}\text { Managerial Competence (X1) -> HR Division } \\
\text { Line Manager Performance (Y) }\end{array}$ & 0.247 & 0.029 & 0.275 & 0.000 \\
\hline $\begin{array}{l}\text { Commitment (X2) -> HR Division Line } \\
\text { Manager Performance (Y) }\end{array}$ & 0.276 & 0.043 & 0.319 & 0.000 \\
\hline $\begin{array}{l}\text { Innovation Capability (X3) -> HR Division } \\
\text { Line Manager Performance (Y) }\end{array}$ & 0.341 & 0.059 & 0.400 & 0.000 \\
\hline $\begin{array}{l}\text { Readiness for Change (X4) -> HR Division } \\
\text { Line Manager Performance (Y) }\end{array}$ & 0.378 & 0.035 & 0.412 & 0.000 \\
\hline
\end{tabular}

Table 3: Total Effects Direct Effect, Indirect Effect, P-Values Notes: * $p<0.05$.

Source: Research Results, 2021

The total influence of Managerial Competence (X1) on HR Division Line Manager Performance $(Y)$ was 0.275 , Commitment (X2) on HR Division Line Manager Performance (Y) was 0.319, Innovation Capability (X3) on HR Division Line Manager Performance $(Y)$ of 0.400 , Readiness for Change (X4) on the HR Division Line Managers Performance (Y) of 0.412 and a significant level $\leq 0.05$ of 0.000 . The coefficient analysis of determination shows the magnitude of the influence of the exogenous variable, the mediating variable (intervening) on the endogenous variables of this study. Structural model testing was done by looking at the R square value obtained from the algorithm procedure on SmartPLS in Table 4: 


\begin{tabular}{|l|l|l|}
\hline & R Square & R Square Adjusted \\
\hline HR Division Line Manager Performance $(\mathrm{Y})$ & 0,859 & 0,853 \\
\hline HR Professional Transformation $(\mathrm{Z})$ & 0,345 & 0,323 \\
\hline
\end{tabular}

Table 4: Coefficient of Determination Value

Source: Research Results, 2021

The $R$ Square value of on the HR Professional Transformation variable $(Z)$ was 0.345 which means that Managerial Competence (X1), Commitment (X2), Innovation Capability (X3), and Readiness for Change (X4) were able to explain the effect as an exogenous variable on the mediating variable (intervening) of $34.5 \%$, the remaining $65.5 \%$ was explained by other variables outside the research model. Furthermore, the value of $\mathrm{R}$ Square on the HR Division Line Manager Performance $(Y)$ was 0.859 which means Managerial Competence (X1), Commitment (X2), Innovation Capability (X3), Readiness for Change (X4) and Professional Transformation of $\mathrm{HR}(\mathrm{Z})$ were able to explain their influence as an exogenous and mediating (intervening) variable of $85.9 \%$, the remaining $14.1 \%$ was also explained by other variables outside this research model.

The model suitability test (goodness of fit test) was conducted for the structural model in measuring how well the observed values produced by the model and also parameter estimates were. The suitability test of this model was also referred as Q2 predictive relevance with the decision criteria, if the value of $\mathrm{Q} 2>0$ indicates that the model has predictive relevance while the value of $\mathrm{Q} 2<0$ indicates that the model lacks predictive relevance. Q2 can be calculated through the following equation: Q2 = 1-(1-R12) $(1-R 22) \ldots \ldots .(1-R p 2)$. The $R 12$ value, $R 22 \ldots \ldots . . R p 2$ was $R$ square of the endogenous variable in the research model, (Noor, 2015). The results of the model suitability test (goodness of fit test) using the $Q$ square equation in this study are: $Q 2=1-(1-$ Professional Transformation of HR) (1- Performance of HR Division Line Managers $)=1-(1-0,345)(1-0.859)=1-(0.655)(0.141)=0.907$. Based on the results of the calculation value of $Q 2$, it can be seen that the value of $\mathrm{Q} 2=0.907>0$ which means the research model of Managerial Competence (X1), Commitment (X2), Innovation Capability (X3), Readiness for Change (X4) HR Professional Transformation (Z) and The HR Division Line Managers Performance $(Y)$ has a very strong predictive relevance value or in other words it can be stated that the research model is Managerial Competence (X1), Commitment (X2), Innovation Capability (X3), Readiness for Change (X4), Professional Transformation HR (Z) (as a novelty variable)

\section{References}

[1] Argyris C, Schon D. A. (1978)-Organizational Learning: A Theory of Action Perspective. Philippines, Addison-Wesley Publishing Company, Inc.

[2] Bag, S., \& Pretorius, J. H. C. (2020). Relationships between industry 4.0, sustainable manufacturing and circular economy: proposal of a research framework. International Journal of Organizational Analysis, ahead-of-print(ahead-of-print). doi:10.1108/ijoa-04-2020-2120

[3] Bayer, O., Krupskyi, O., \& Bondarenko, E. (2020). Subordinate evaluations of high-performance managers. Leadership \& Organization Development Journal, 41(7), 927938. doi:10.1108/lodj-02-2019-0080

[4] Becker B.E., Huselid M. A, Ulrich, D. (2001). The HR Scorecard Linking People Strategy and Performance. Massachusetts, Harvard Business School Press

[5] Becker Gary S. (1964), (1975), (1993). Human Capital A Theoretical and Empirical Analysis, with Special Reference to and HR Division Line Manager Performance (Y), if applied, it is predicted to be able to achieve company success of $90.7 \%$.

\section{Conclusion}

The conclusion in this study showed evidence that managerial competence, commitment, innovation capability, and readiness for change can improve the HR Division Line Managers Performance through professional transformation of human resources which has been proven to be positive in achieving company success". The application of HR professional transformation can be implemented through business intelligence as a business decision-making ability that must be possessed by line managers in the HR division. Business intelligence combines human skills, technology and business processes to make better business strategy decisions. Implementation The next HR professional transformation can be implemented through the use of artificial intelligence. HR division line managers who use artificial intelligence will master information technology skills that can spur the HR division line managers' ability to communicate with employees through technology, assisting companies in overseeing all elements of business processes aimed at increasing flexibility, speed, and quality of decisions in HR management. The use of artificial intelligence can also automate manual work to eliminate work errors that are generally caused by humans. The HR professional transformation was conducted by redesigning the functions of the HR division, focusing on system collaboration between HR divisions, implementing partnership skills, and increasing accountability in the business. Implementing a collaborative system between HR divisions will be able to spur the completion of the company's vision, and build interrelated systems to address problems and opportunities. Implementing partnership skills will form a partnership that can increase company profits and also by increasing accountability in the company's business, will create continuous employee development so that work results are achieved properly.

Education Third Edition. By The National Bureau of Economic Research All rights reserved. Published 1993. Chicago and London, The University of Chicago Press

[6] Cooke, F. L., Xiao, Q., \& Xiao, M. (2020). Extending the frontier of research on (strategic) human resource management in China: a review of David Lepak and colleagues' influence and future research direction. The International Journal of Human Resource Management, 32(1), 183-224. doi:10.1080/09585192.2020.1803949

[7] Colquitt J. A., Lepine J. A., Wesson M. J. (2019). Organizational Behavior : Improving Performance And Commitment In The Workplace, Sixth Edition. United State America, Mc Graw Hill Cengage Learning.

[8] Fareed M, Ahmad A, Salleh S. S. M. M, Saoula O. (2020). What makes HR Professionals Effective? Qualitative Evidence from Telecom Sector of a Developing Country. Revista Argentina de Clínica Psicológica, 28(4), pp. 603-617, DOI: 10.24205/03276716.2019.1141

[9] Fu, N., Flood, P. C., Rousseau, D. M., \& Morris, T. (2018). Line Managers as Paradox Navigators in HRM 
Implementation: Balancing Consistency and Individual Responsiveness. Journal of Management, 46(2), 203-233. doi:10.1177/0149206318785241

[10] Van den Heuvel, S., \& Bondarouk, T. (2017). The rise (and fall?) of HR analytics. Journal of Organizational Effectiveness: People and Performance, 4(2), 157-178. doi:10.1108/joepp03-2017-0022

[11] Jackson, S. E., Schuler, R. S., \& Jiang, K. (2014). An Aspirational Framework for Strategic Human Resource Management. The Academy of Management Annals, 8(1), 156. doi:10.1080/19416520.2014.872335

[12] Karakoc N. (2020). Firms Under New Competition Conditions and Strategic Manager Capabilities. KOCATEPEIIBF Dergisi, Haziran, 22(1), 1-13.

[13] Kirrane M, Lennon M, O'Connor C, Fu N. (2017). Linking perceived management support with employees' readiness for change: the mediating role of psychological capital, Journal of Change Management, http://dx.doi.org/10.1080/14697017.2016.1214615, pp. 1-20

[14] Kokubun, K., \& Yasui, M. (2020). The difference and similarity of the organizational commitment-rewards relationship among ethnic groups within Japanese manufacturing companies in Malaysia. International Journal of Sociology and Social Policy, 40(11/12), 1391-1421. doi:10.1108/ijssp-032020-0099

[15] Kosasih, K., Wibowo, W., \& Saparuddin, S. (2020). The influence of ambidextrous organization and authentic followership on innovative performance: The mediating role of change readiness. Management Science Letters, 1513-1520. doi:10.5267/j.msl.2019.12.015

[16] Kehoe, R. R., \& Han, J. H. (2020). An expanded conceptualization of line managers' involvement in human resource management. Journal of Applied Psychology, 105(2), 111-129. doi:10.1037/apl0000426

[17] Latham G (2018). Becoming the Evidence Based ManagerMaking the Science of Management Work For You, Second Edition, United States of America, Nicholas Brealey Publishing

[18] Le, P. B., \& Lei, H. (2019). Determinants of innovation capability: the roles of transformational leadership, knowledge sharing and perceived organizational support. Journal of Knowledge Management, 23(3), 527-547. doi:10.1108/jkm09-2018-0568

[19] Lee Q.Y, Townsend K, Wilkinson A. (2020). Frontline Managers'implementation of the Formal and Informal Performance Management Systems. Personnel Review, Emerald Publishing Limited, DOI 10.1108/PR-11-2019-0639

[20] Liu, Y. (2017). Review of Human Resource Management Function of Frost Line Manager. Open Journal of Business and Management, 671-679. doi:10.4236/ojbm.2017.54056

[21] Losey, Meisinger S., Ulrich D. (2005). The Future of Human Resources Management. New Jersey, John Wiley and Sons, Inc., Hoboken.

[22] Lupicka A, Grzybowska K. (2018). Key Managerial Competencies for Industry 4.0-Practitioners, Researchers and Students Opinions. Logistics and Transport Journal, pp. 3946, DOI:10.26411/83-1734-2015-3-39-4-18

[23] Morkovkin, D. E., Gibadullin, A. A., Kolosova, E. V., Semkina, N. S., \& Fasehzoda, I. S. (2020). Modern transformation of the production base in the conditions of Industry 4.0: problems and prospects. Journal of Physics: Conference Series, 1515(3), $032014 . \quad$ doi:10.1088/17426596/1515/3/032014

[24] Matthysen, M., \& Harris, C. (2018). The relationship between readiness to change and work engagement: $A$ case study in an accounting firm undergoing change. SA Journal of Human Resource Management, 16. doi:10.4102/sajhrm.v16i0.855

[25] Mendoza-Silva, A. (2020). Innovation capability: a systematic literature review. European Journal of Innovation Management, 24(3), 707-734. doi:10.1108/ejim-09-2019-
0263

[26] Mercer (2021). Menang dengan Empati. Tren Talenta Global 2020-2021, Laporan Rekanan Lokal, Edisi Indonesia

[27] Mitchell B, Gamlem C (2017). The Big Book of HR, Revised and Updated Edition. Canada, The Career Press.

[28] Mtetwa T. N, Mutambara E (2020). Human Resource Transformation As A Panacea For Addressing Talent Management Challenges At An Electricity Company. The Ife Centre for Psychological Studies, Nigeria, ISSN: 1596-9231, 18(4), pp. 16623-16635

[29] Ben Moussa, N., \& El Arbi, R. (2020). The impact of Human Resources Information Systems on individual innovation capability in Tunisian companies: The moderating role of affective commitment. European Research on Management and Business Economics, 26(1), 18-25. doi:10.1016/j.iedeen.2019.12.001

[30] Nham, T. P., Nguyen, T.-M., Tran, N. H., \& Nguyen, H. A. (2020). Knowledge sharing and innovation capability at both individual and organizational levels: An empirical study from Vietnam's telecommunication companies. Management \& Marketing. Challenges for the Knowledge Society, 15(2), 275-301. doi:10.2478/mmcks-2020-0017

[31] Niazi A, Faraz H. A, Arshad B, Asghar W (2020). Impact of Managerial Competency and Learning Orientation on Job Performance. Journal of Accounting and Finance in Emerging Economies, 6(3), 885-896

[32] Noor J. (2015). Analisis Data Penelitian Ekonomi dan Manajemen. Penerbit: Gramedia Widiasarana Indonesia, Jakarta.

[33] Panagiotakopoulos, A. (2020). Exploring the link between management training and organizational performance in the small business context. Journal of Workplace Learning, 32(4), 245-257. doi:10.1108/jwl-10-2019-0121.

[34] Panda P. (2020). The Future Transformation of Hr Functions Which Apstole by Artificial Intelligence. Brindavan Journal of Management and Computer Science, National Conference Proceedings, 1(1), pp. 127-135.

[35] Paulienè, R. (2021). Interaction Between Managerial Competencies and Leadership in Business Organisations. Regional Formation and Development Studies, 21(1), 97107. doi:10.15181/rfds.v21i1.1412

[36] Muñoz-Pascual, L., Galende, J., \& Curado, C. (2019). Human Resource Management Contributions to Knowledge Sharing for a Sustainability-Oriented Performance: A Mixed Methods Approach. Sustainability, 12(1), 161. doi:10.3390/su12010161

[37] PT. Sarana Multi Infrastuktur (Persero). (2021). Laporan Hasi Kajian Dlvisi Riset Ekonomi. Potret Ekonomi Indonesia di Tengah Pandemi Covid-19: Kumpulan Studi untuk Pemulihan Ekonomi Indonesia

[38] Purba P, Dalimunthe R. F, Absah Y (2020). The Effect of Work Skills and Employee's Job Involvement on Employee Performance Through Job Satisfaction In Manpower Office Of Medan, Indonesia. European Journal of Human Resource Management Studies 4(2). Pp.169-188, DOI: 10.5281/zenodo.3829741

[39] Ridell R. V, Roisland M. T (2017). Change Readiness: Factors Influencing Employees' Readiness For Change Within an Organisation: A Systematic Review, Master's theses in Business Administration, Department of Economics and Finance, University of Agder, Kristiansand, Norwegia

[40] Saunila, M. (2020). Innovation capability in SMEs: A systematic review of the literature. Journal of Innovation \& Knowledge, 5(4), 260-265. doi:10.1016/j.jik.2019.11.002

[41] Schuler R. S, Walker J. W. (1990). Human Resources Strategy: Focusing on Issues and Action. Academy of Management

[42] Schuler, R. S., \& Jackson, S. E. (2005). A Quarter-Century Review of Human Resource Management in the U.S.: The Growth in Importance of the International Perspective. Management Revu, 16(1), 11-35. doi:10.5771/0935-99152005-1-11 


\section{GENERAL MANAGEMENT}

[43] Sekaran U, Bougie R. (2016). Research Methods for Business A Skill-Building Approach Seventh Edition, ISBN: 9781119165552, United Kingdom: John Wiley dan Sons

[44] Shun, H., \& Wang, K. (2020). The Application of a Managerial Competency Model in Employee Promotion-Combination of AHP and VIKOR Methodology. International Journal of Business and Management, 15(7), 77. doi:10.5539/ijbm.v15n7p77

[45] Sotnikova, Y., Nazarova, G., Nazarov, N., \& Bilokonenko, H. (2021). DIGITAL TECHNOLOGIES IN HR MANAGEMENT. Management Theory and Studies for Rural Business and Infrastructure Development, 42(4), 527-535. doi: $10.15544 / \mathrm{mts} .2020 .54$

[46] Sousa, M. J., \& Dias, I. (2020). Business Intelligence for Human Capital Management. International Journal of Business Intelligence Research, 11(1), 38-49. doi:10.4018/ijbir.2020010103

[47] Subramony, M., Guthrie, J. P., \& Dooney, J. (2020). Investing in HR? Human resource function investments and labor productivity in US organizations. The International Journal of Human Resource Management, 32(2), 307-330. doi:10.1080/09585192.2020.1783343
[48] Torraco, R. J., \& Lundgren, H. (2019). What HRD Is DoingWhat HRD Should be Doing: The Case for Transforming HRD. Human Resource Development Review, 19(1), 39-65. doi:10.1177/1534484319877058

[49] Ulrich D., Allen J. Brockbank W, Younger J, Nyman M. (2009). HR Transformation: Building Human Resources from the Outside In. The RBL Institute, USA, McGraw-Hill Books.

[50] Vallina A. S, Alegre J, Cabrales A. L (2021). The Challenge of Increasing Employees' Well-Being and Performance: How Human Resource Management Practices and Engaging Leadership Work together toward Reaching this Goal. Human Resource Management, wileyonlinelibrary.com/journal/hrm. pp.1-15. DOI: 10.1002/hrm.22021.

[51] Yeung A. K, Ulrich D., Nason S.W., Mary A.V.G. (1999) Organizational Learning Capability, New York, Oxford University Press, Inc.

[52] Zeidan S., Itani N. (2020). HR Analytics and Organizational Effectiveness. International Journal on Emerging Technologies 11(2): pp. 683-688. 